TITLE:

\title{
Cnidome and Growth of a Medusa of Cirrholovenia tetranema (Leptomedusae, Cirrholoveniidae) in Japan
}

$\operatorname{AUTHOR}(\mathrm{S})$ :

Kubota, Shin

\section{CITATION:}

Kubota, Shin. Cnidome and Growth of a Medusa of Cirrholovenia tetranema

(Leptomedusae, Cirrholoveniidae) in Japan. PUBLICATIONS OF THE SETO MARINE BIOLOGICAL LABORATORY 1995, 36(5-6): 365-378

ISSUE DATE:

1995-07-31

URL:

http://hdl.handle.net/2433/176244

RIGHT: 


\title{
Cnidome and Growth of a Medusa of Cirrholovenia tetranema (Leptomedusae, Cirrholoveniidae) in Japan
}

\author{
Shin Kubota \\ Seto Marine Biological Laboratory, Kyoto University, \\ Shirahama, Wakayama 649-22, Japan
}

With Text-figures $1-9$ and Tables $1-4$

\begin{abstract}
The cnidome, growth of a medusa, as well as the gametes and spawning time, of Cirrholovenia tetranema Kramp (Leptomedusae, Cirrholoveniidae) were studied for the first time. The medusae were collected from six localities: Tsushima Island (Nagasaki Prefecture) as the northernmost geographical distribution in the Pacific; Matsuyama (Ebime Pref.); Shirahama (Wakayama Pref.); Amamioshima Island (Kagoshima Pref.); Tomari in Okinawa Island and Aka in Akajima Island (Okinawa Pref.). These are the first record of this species from each locality and the first record of this species in Japan. The morphological characteristics of the medusae caught in the sea generally agree with those reported earlier from other regions in the world. However, the medusae reared in the laboratory exhibited considerable morphological differences, which are highlighted here. Geographical distribution is also mentioned.
\end{abstract}

\section{Introduction}

The hydrozoan family Girrholoveniidae Bouillon, 1984 contains two genera, Cirrholozenia Kramp, 1959 and Paralovenia Bouillon, 1984 (Bouillon, 1984a, b; 1985). Recently many medusae belonging to the former genus were collected by the author from six localities in Japan. They were identified as C. tetranema Kramp, 1959, being apparently different from C. polynema Kramp, 1959, the type species of the genus.

Some of these medusae were reared under controlled laboratory conditions until they became inactive or were attacked by the protozoans, and the morphological changes were observed. The cnidome, the gametes and spawning time of this species were observed for the first time. The morphological differences between the present specimens and those described from other regions of the world are pointed out.

\section{Material and Methods}

A total of 33 medusae were collected from six localities around Japan as described below (Fig. 1). Their morphology was observed immediately or within four days after capture under a stereoscopic and a light microscope. Some of them were brought back to the laboratory and reared in filtered seawater at $22^{\circ} \mathrm{C}$ in $60 \mathrm{ml}$ polystyrene vessels under alternating $12 \mathrm{~h}$ periods of light and dark until they became inactive. They were fed with Artemia nauplii. The seawater was changed every day.

From Tsushima Island, Nagasaki Prefecture, at the entrance of the Sea of Japan, two medusae were collected alive, scooping gently in a $60 \mathrm{ml}$ polystyrene vessel by hand on August 20, 1992. They were swimming in a medusan swarm at subsurface depth along the coast of Takeshiki in Asou Bay (Fig. 1, T). The smaller specimen was preserved soon after collection and examined later (measurements were

Publ. Seto Mar. Biol. Lab., 36(5/6), 365-378, 1995.

(Article 29) 


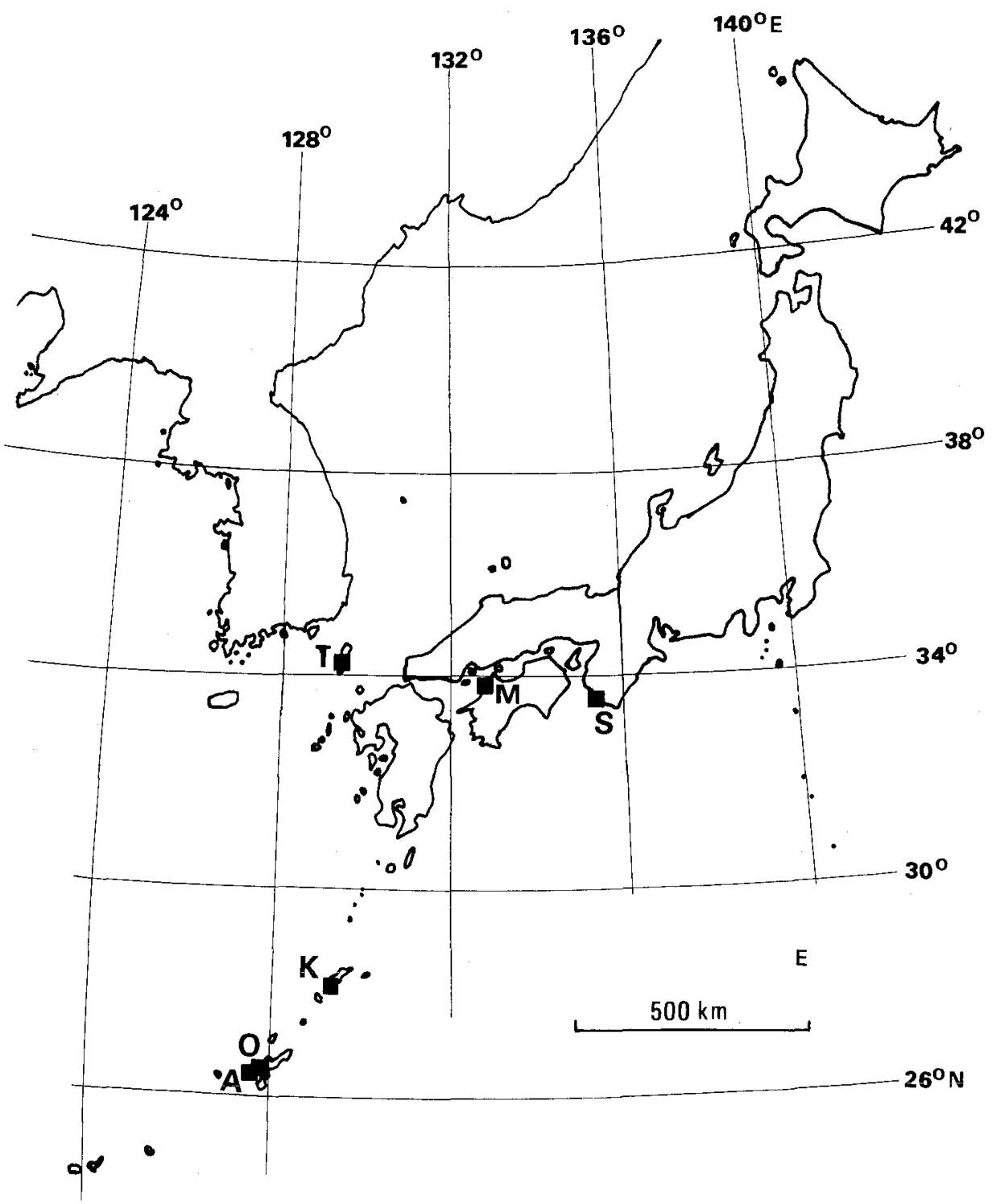

Fig. 1. Localities from which medusae of Cirrholovenia tetranema were collected. A: Akajima Island. K: Koniya, Amamioshima Island. M: Mitsuhama, Ehime Prefecture. O: Tomari, Okinawa Island. S: Shirahama, Wakayama Prefecture. T: Takeshiki, Tsushima Island.

partly possible), while the larger one was brought alive to the laboratory. On the 4 th day after collection it was anesthetized by $\mathrm{MgCl}_{2}$ solution and examined in detail. On Scptember 28, 1994 another specimen was collected from the same locality by towing a plankton net in the upper $8 \mathrm{~m}$.

On August 7, 1993 three medusae were collected at Mitsuhama port, Matsuyama, Ehime Prefecture in the Inland Sea of Japan by vertical towing of a plankton net at $10-0 \mathrm{~m}$ (Fig. 1, M). Their morphology was examined on the next day in the laboratory, and the growth of two medusae were observed together with the cnidome.

Two medusae were collected at Koniya port, Setouchi-cho, Amamioshima Island, Kagoshima Prefecture 
by horizontal and vertical (from $8 \mathrm{~m}$ depth to surface) towing of a plankton net on October 11, 1993 (Fig. 1, K). The morphology of these spccimens, one preserved in situ and the other reared in the laboratory, was observed.

At Shirahama, Wakayama Prefecture (Fig. 1, S: $33^{\circ} 41.5^{\prime} \mathrm{N}, 135^{\circ} 18.4^{\prime} \mathrm{E}$ ) one specimen was collected by vertical (in the upper $30 \mathrm{~m}$ ) towing a plankton net on December 2, 1993. It was examined immediately after collection.

At Aka port, Akajima Island, Okinawa Prefecture a total of 23 specimens were collected at 5-0 m depth during 21st to 23rd November, 1993 and 10th to 12th March, 1994 (Fig. 1, A). They were examined immediatcly or within a few days after collection. Some of these specimens were reared in the laboratory for a maximum period of one month to observe their gametes and also to record their spawning time.

One specimen caught in the upper $7 \mathrm{~m}$ depth on March 12, 1994 at Tomari port, Okinawa Island, Okinawa Prefecture was examined after two and seven days after its collection (Fig. 1, O).

The figures 2 and 6-8 were drawn with the aid of a drawing tube attached to a phase-contrast microscope. Photographs were taken in a living specimen (Figs. 3, 4).

\section{Description}

The morphology of a medusa caught in the sea is described first, following the synonymy. Then the growth of medusa is described together with the cnidome, the gametes, and spawning time as well as the remarks and the geographical distribution.

\section{Cirrholovenia tetranema Kramp, 1959}

(Figs, 2-8)

Cirrholovenia letranema Kramp, 1959, pp. 253-254, Figs. 17a, b; —, 1961, p. 173; —, 1968, p. 80, Fig. 214; Brinckmann, 1965, pp. 13-15, Fig. 1; Brinckmann-Voss, 1987, p. 137; Allwein, 1967, p. 122 , p. 129 ; Moreira, 1967 , pp. $426-427$; —, 1975, pp. $556-557$; -, 1978 , pp. 47-48; Navas, 1971 , p. 5 , p. 11, p. 17; — 1981 , p. 235, pp. 254-255; Goy, 1972, pp. 991-992; 1979, p. 276, Fig. 14; — Lakkis \& Zeidane, 1990, p. 82, 86; - - - \& 113-114, 123-124, Fig. 35; Bouillon, 1978, p. 125; $\div$, 1984b, p. 27; Xu \& Zhang, 1981, p. 374, p. 377, p. 382, Fig. 8; Mao \& Jinbiao, 1991, p. 304; Lakkis, 1991, p. 125.

Eugymnanthea minuta Uchida, 1964, pp. 101-104, pp. 106-107, Figs. 1a, 1b, Figs. 2, 3; Recs, 1967, p. 221.

Morphology of medusa caught in the sea

The umbrella is up to $1.35 \mathrm{~mm}$ in diameter and $1.25 \mathrm{~mm}$ in height (Table 1). The mesogloea is generally thin, with a maximum thickness of $0.13 \mathrm{~mm}$ at the umbrellar apex. In an immature medusa exumbrellar nematocysts are sparsely found (Fig. 2, A). The manubrium is tubular and short, up to $0.35 \mathrm{~mm}$ long. No peduncle is present. Four oral lips are simple. Four tentacles extend from conical tentacular bulbs. No marginal warts are present (Figs. 2, 3). There are usually four, rarely five or six statocysts, and one statocyst in each of the interradial portion of the umbrellar margin, but sometimes near the tentacular bulbs (Fig. 2, A). Each statocyst contains a single statolith but very rarely two are also present (Fig. 2, A). Lateral cirri are absent. In each quadrant a maximum number of seven marginal cirri were found. In a medusa up to 26 cirri were observed. Four gonads extend from the stomach base along the four radial canals, but do not reach the umbrellar margin. The gonads are smooth. The medusa is transparent. 
Table 1. Some taxonomic characters of the medusa of Cirrholovenia tetranema caught in the sea around Japan. Measurements were taken within four days after collection. Blank: Not measured due to modification of shape.

\begin{tabular}{|c|c|c|c|c|c|c|c|}
\hline Sex & $\begin{array}{l}\text { Diameter } \\
(\mathrm{mm})\end{array}$ & $\begin{array}{c}\text { Height } \\
(\mathrm{mm})\end{array}$ & $\begin{array}{l}\text { Thickness } \\
\text { of jelly at } \\
\text { umbrellar } \\
\text { apex }(\mathrm{mm})\end{array}$ & $\begin{array}{l}\text { Length of } \\
\text { manubrium } \\
(\mathrm{mm})\end{array}$ & $\begin{array}{l}\text { Total } \\
\text { number } \\
\text { of stato- } \\
\text { cysts }\end{array}$ & $\begin{array}{c}\text { Total } \\
\text { number } \\
\text { of stato- } \\
\text { liths }\end{array}$ & $\begin{array}{l}\text { No. of marginal } \\
\text { cirri in each } \\
\text { quadrant (or in } \\
\text { two bulbs) }\end{array}$ \\
\hline \multicolumn{8}{|c|}{ Takeshiki, Tsushima Is. } \\
\hline Female & 0.93 & 0.63 & 0.08 & 0.13 & 4 & 4 & $5,4,4,4$ \\
\hline$?$ & 0.75 & 0.48 & 0.03 & 0.10 & 4 & & $3,3,3,3$ \\
\hline$?$ & & & & & 4 & 4 & $\max .7$ \\
\hline \multicolumn{8}{|l|}{ Mitsuhama } \\
\hline Male & 0.88 & 0.65 & 0.08 & 0.25 & 4 & 4 & $5,2,4,3$ \\
\hline$?$ & 0.88 & 0.63 & 0.13 & 0.15 & 4 & 5 & $3,2,1,2$ \\
\hline$?$ & 0.78 & 0.50 & 0.08 & 0.15 & 4 & 4 & $2,2,2,2$ \\
\hline \multicolumn{8}{|l|}{ Shirahama } \\
\hline$?$ & 1.20 & 0.98 & 0.05 & $0.35 * *$ & 6 & 6 & $4,4,4,3$ \\
\hline \multicolumn{8}{|c|}{ Koniya, Amamioshima Is. } \\
\hline Male & 1.30 & 1.25 & 0.05 & 0.23 & 4 & 3 & $5,5,4,4$ \\
\hline Male & & & & & 5 & 5 & $6,4,4,4$ \\
\hline \multicolumn{8}{|c|}{ Tomari, Okinawa Is. } \\
\hline$?$ & 0.83 & & & & 3 & 2 & $3,3,2,2$ \\
\hline \multicolumn{8}{|c|}{ Aka, Akajima Is. } \\
\hline Female & 1.35 & & & & 4 & 4 & $4,4,3,3$ \\
\hline Female & 1.08 & 0.90 & 0.08 & & 4 & 4 & $3,3,2,2$ \\
\hline Female & 1.02 & 0.78 & 0.05 & 0.24 & 4 & 4 & $6,5,2,3$ \\
\hline Female & & & & & 4 & 4 & $7,6,7,6$ \\
\hline Female* & & & & & 3 & 3 & $6,6,6,5,2$ \\
\hline Male & 1.35 & 1.00 & 0.10 & & 4 & 4 & $5,4,4,4$ \\
\hline Male & 1.23 & 0.88 & & & 4 & 4 & $4,4,4,3$ \\
\hline Male & 1.12 & 0.80 & 0.07 & 0.24 & 4 & 4 & $6,3,5,5$ \\
\hline$?$ & 1.30 & 0.98 & 0.05 & & 4 & 4 & $4,3,3,3$ \\
\hline$?$ & 1.28 & & & & 4 & 4 & $4,4,3,3$ \\
\hline$?$ & 1.28 & 0.85 & & & 4 & 4 & $3,3,3,2$ \\
\hline$?$ & 1.10 & 0.93 & 0.05 & & 4 & 4 & $5,4,4,4$ \\
\hline$?$ & 1.10 & 0.88 & 0.10 & & 4 & 4 & $4,4,4,3$ \\
\hline$?$ & 1.05 & 0.80 & 0.08 & & 4 & 4 & $3,2,3,2$ \\
\hline$?$ & 1.03 & 0.93 & 0.05 & & 4 & 4 & $4,4,3,3$ \\
\hline$?$ & 0.98 & 0.80 & 0.07 & 0.24 & 4 & 4 & $5,4,4,4$ \\
\hline$?$ & 0.98 & 0.78 & 0.05 & 0.20 & 4 & 3 & $3,3,3,3$ \\
\hline$?$ & 0.90 & 0.63 & 0.07 & 0.15 & 4 & 4 & $4,4,4,4$ \\
\hline$?$ & 0.90 & 0.83 & 0.07 & 0.22 & 4 & 4 & $4,4,4,3$ \\
\hline$?$ & 0.90 & 0.73 & & & 4 & 4 & $3,3,3,2$ \\
\hline$?$ & 0.90 & 0.75 & 0.08 & & 4 & 4 & $3,2,2,2$ \\
\hline$?$ & 0.88 & 0.68 & 0.05 & & 4 & 4 & $3,3,2,2$ \\
\hline ?* & 1.05 & 0.78 & 0.08 & & 5 & 5 & $4,3,3,3,3$ \\
\hline
\end{tabular}

*: Specimens with five radial canals. **: Larger one of the two manubria. 

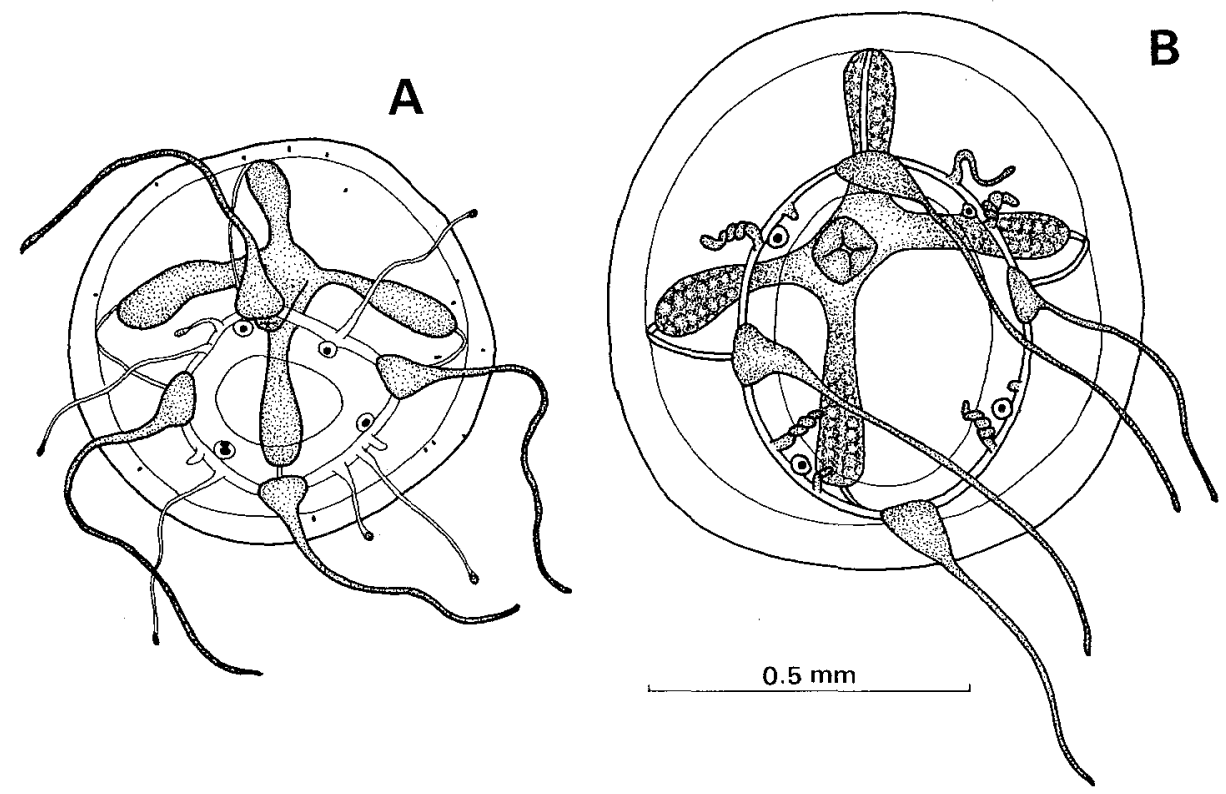

Fig. 2. Morphology of the medusa of Cirrholovenia tetranema. A: Oblique view of immature specimen from Mitsuhama. Note the position of two statocysts which are not found interradially, one statocyst containing two statoliths, and the presence of the exumbrellar nematocysts. B: Oral view of a female specimen from Tsushima Island. Note that decrease in number of the marginal cirri within four days after collection (see Table 1).

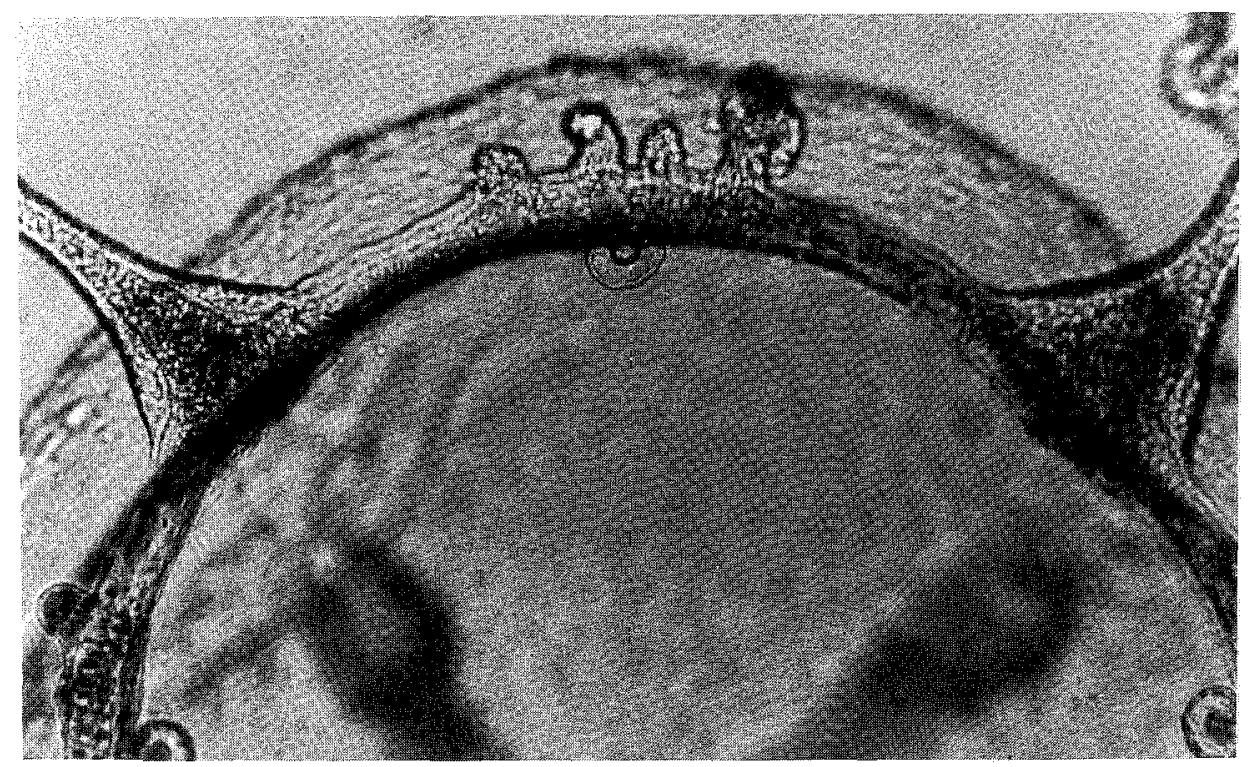

Fig. 3. Part of umbreilar margin of Cirrholovenia teiranema from Akajima Island (Aboral view). 
As an exception, one specimen collected from Shirahama had two manubria and two specimens collected from Akajima Island had five radial canals (Table 1). Although the female specimen from Akajima Island had five radial canals and five tentacular bulbs, it had only three statocysts as the minimal number of statocysts per medusa.

\section{Growth of medusa in the laboratory}

Medusae caught in the sea usually grow in the laboratory even if after maturation. A medusa collected from Mitsuhama grew up to $1.28 \mathrm{~mm}$ in diameter after 10 days of its collection (Fig. 5, B), Another one from Amamioshima Island (Fig. 4) grew up to $2.38 \mathrm{~mm}$ in diameter after 13 days (Fig. 5, C) and a female specimen from Akajima Island grew to $2.50 \mathrm{~mm}$ in diameter after 22 days.

The marginal cirri increased in number in every specimen (Fig. 5, A-C), reaching to a maximum of 51 per medusa (Fig. 5, C). The maximum number of marginal cirri in a quadrant was 15 (Tables 1,2 ).

The number of tentacles became five due to the formation of one tentacular bulb interradially in a medusa from Amamioshima Island (Table 2).

The number of statoliths per statocyst is usually constant (1 per statocyst), while the number of statocysts increased, reaching to a maximum of nine (Fig. 5, C). The maximum number of statoliths per statocyst was four in a 33-day-old female specimen from Akajima Island, which grew as the largest specimen in the present study $(2.50$ $\mathrm{mm}$ in diameter). A total of 17 statoliths were found in this specimen (each statocyst contained $3,2,2,2,2,4,1,1$ statoliths).

The four oral lips remains simple (Fig. 6, B).

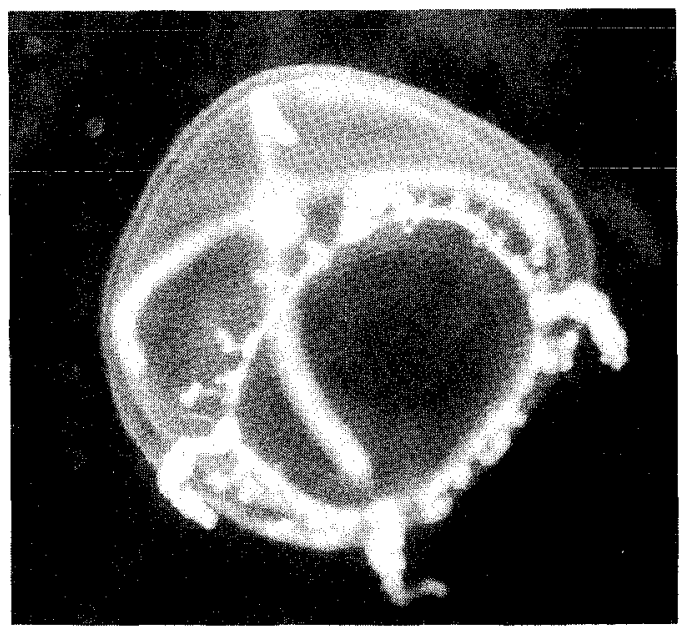

Fig. 4. A spent male medusa of Cirrholovenia tetranema reared for eight days after collection at Amamioshima Island (2.08 $\mathrm{mm}$ in diameter). 


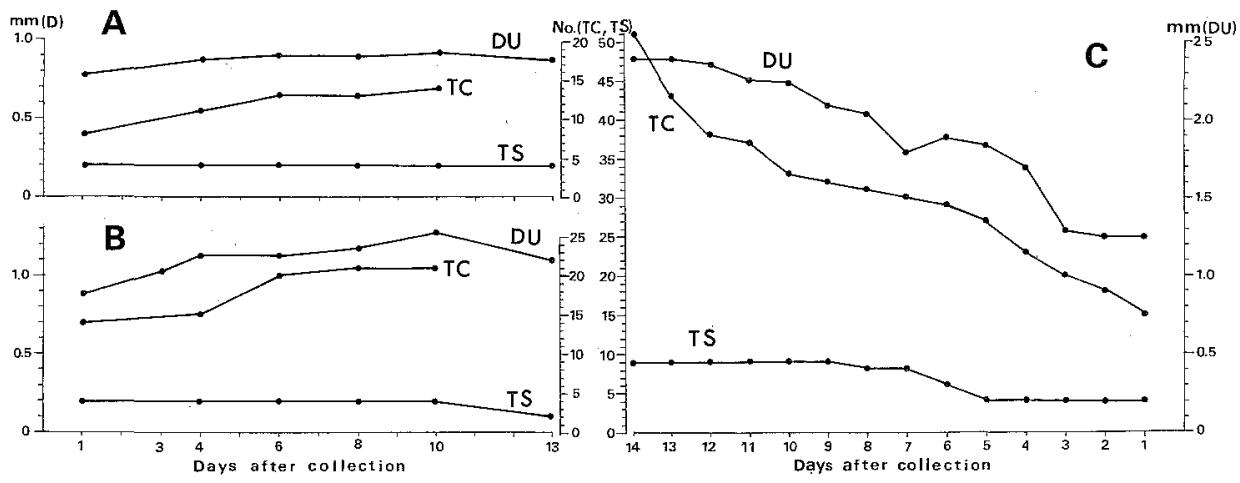

Fig. 5. Growth of three medusae of Cirrholovenia tetranema, two from Mitsuhama (A, B) and one from Amamioshima Island (C). DU: Diameter of umbrella. TC: Total number of the marginal cirri per medusa. TS: Total number of the statocysts per medusa.

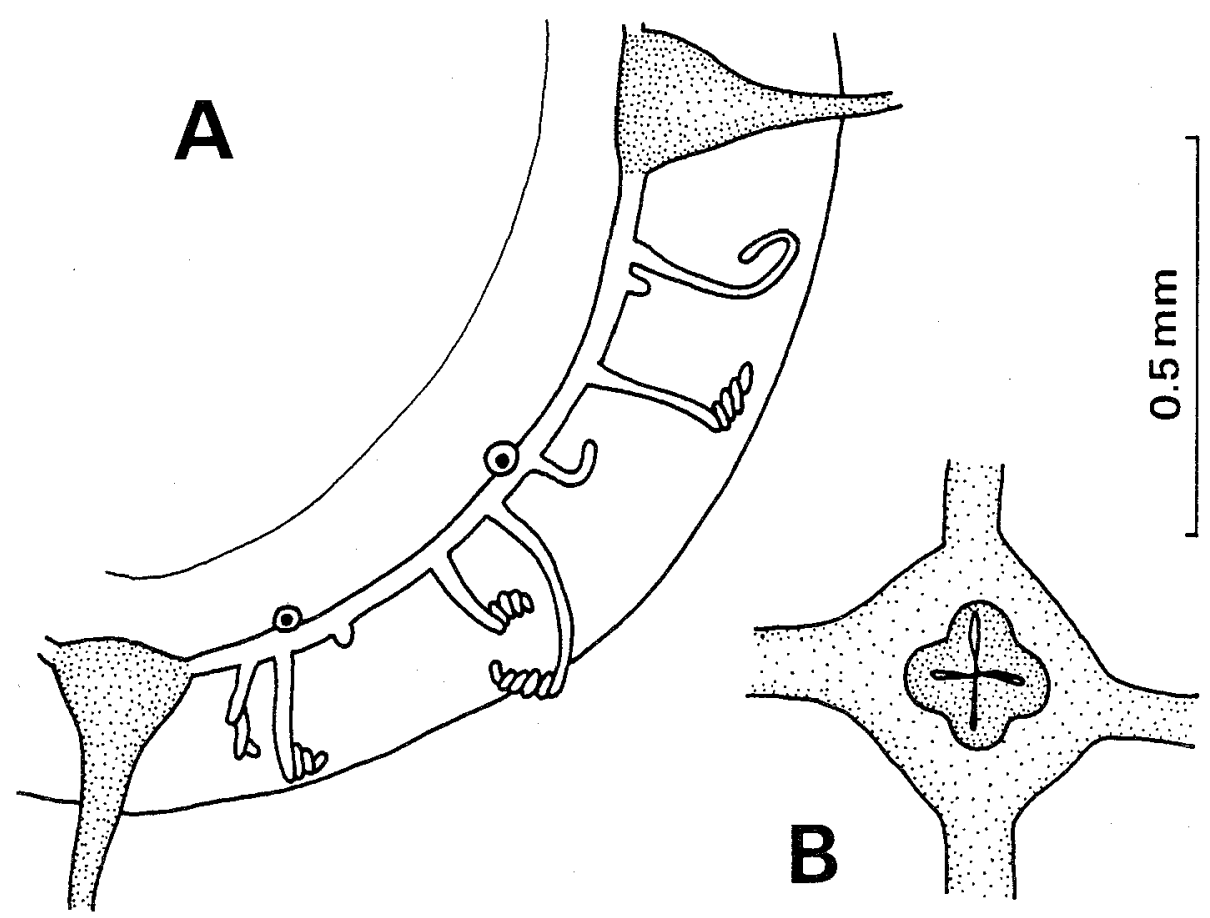

Fig. 6. Body portions of a laboratory-reared medusa of Cirrholovenia tetranema from Amamioshima Island. A: Umbreliar margin of a quadrant, showing two statocysts and nine marginal cirri (7-day-old stage). B: Crusiform oral lips and the broad stomach (14-day-old stage).

\section{Regeneration}

Regeneration of the tentacular bulbs, statocysts and marginal cirri was observed in one male specimen from Akajima Island on the 4th day after nearly half of body 
Table 2. Daily change of the number of marginal cirri, statocysts, and of the tentacular bulbs in each quadrant of one medusa from Amamioshima Island (see Fig. 5, C).

\begin{tabular}{|c|c|c|c|}
\hline $\begin{array}{l}\text { Age } \\
\text { (days) }\end{array}$ & $\begin{array}{l}\text { Number in each quadrant: } \\
\text { marginal cirri }\end{array}$ & statocysts & tentacular bulbs \\
\hline 1 & $3,4,4,4$ & $1,1,1,1$ & $1,1,1,1$ \\
\hline 2 & $4,4,5,5$ & $1,1,1,1$ & $1,1,1,1$ \\
\hline 3 & $5,5,5,5$ & $1,1,1,1$ & $1,1,1,1$ \\
\hline 4 & $5,6,6,6$ & $1,1,1,1$ & $1,1,1,1$ \\
\hline 5 & $6,7,7,7$ & $1,1,1,1$ & $1,1,1,1$ \\
\hline 6 & $6,8,7,8$ & $1,1,2,2$ & $1,1,1,1$ \\
\hline 7 & $6,7,8,9$ & $2,2,2,2$ & $1,1,1,1$ \\
\hline 8 & $7,8,7,9$ & $2,2,2,2$ & $1,1,1,1$ \\
\hline 9 & $8,8,7,9$ & $2,2,2,3$ & $1,1,1,1$ \\
\hline 10 & $8,8,8,9$ & $2,2,2,3$ & $1,1,1,1$ \\
\hline 11 & $8,10,9,10$ & $2,2,2,3$ & $1,1,1,1^{*}$ \\
\hline 12 & $9,10,10,9$ & $2,2,2,3$ & $1,1,1,1^{*}$ \\
\hline 13 & $10,12,10,11$ & $2,2,2,3$ & $1,1,1,2$ \\
\hline 14 & $15,14,10,12$ & $2,2,2,3$ & $1,1,1,2$ \\
\hline 15 & $9,12,10,5$ & $2,2,2,3$ & $1,1,1,2$ \\
\hline 16 & & & \\
\hline
\end{tabular}

*: One marginal wart was produced besides four tentacular bulbs.

-: Data unavailable due to degeneration by attack of protozoans.

was cut off for observation of the sperm (see below). This specimen with its intact manubrium fed on Artemia larvae and produced a total number of six tentacles, seven statocysts, and ten statoliths (three statocysts contained two statoliths) on the 9th day of its regeneration. Thus it appeared as a medusa of different morphology from the initial ordinary one.

\section{Cnidome}

Two kinds of nematocysts are present (Fig. 7, Table 3), though the exumbrellar nematocysts were not examined. The largest nematocysts are on the terminal knob of the marginal cirri; they belong to the basitrichous isorhizas (Fig. 7, Bb). Their number in each cirrus was 11-19 with the mean and standard deviation of $15.8 \pm 2.1$ $(\mathrm{N}=14$, examined in two medusae). The smallest nematocysts are on the distal portion of the marginal cirrus but not on its terminal knob; they belong to the atrichous isorhizas (Fig. 7, A). Two types of atrichous isorhizas, a larger type and a smaller one (Fig. 7, Cc, Dd), are present on the tentacles. The basitrichous isorhizas are also present on both tentacle and manubrium (Fig. 7, Ee, F). 


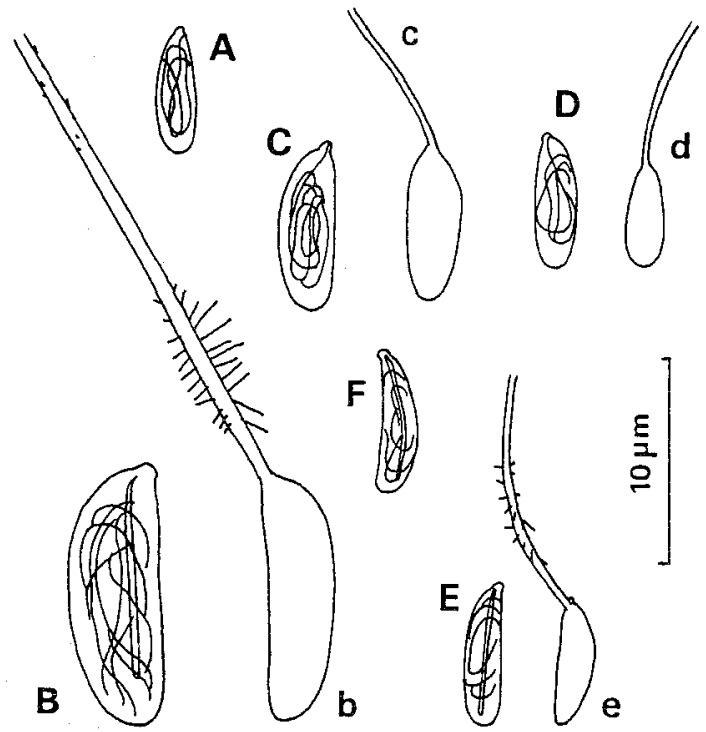

Fig. 7. Nematocysts of the medusa of Cirrholovenia tetranema. A, Gc, Dd: atrichous isorhizas; Bb, $\mathrm{Ee}, \mathrm{F}$ : basitrichous isorhizas. $\mathrm{A}, \mathrm{Bb}$ : on the marginal cirri; $\mathrm{Cc}-\mathrm{Ee}$ : on the tentacles; $\mathrm{F}$ : on the manubrium.

Table 3. Distribution of nematocysts of medusa of Cirrholovenia tetranema. Dimensions áre length $\mathrm{x}$ maximum width of undischarged capsules, in $\mu \mathrm{m}$. Dimensions are mean $\pm \mathrm{SD}$, range and the number of nematocysts and medusae examined.

\begin{tabular}{|c|c|c|}
\hline & Atrichous isorhizas & Basitrichous isorhizas \\
\hline \multirow[t]{2}{*}{ Tentacles } & $\begin{array}{l}8.1 \pm 0.3 \times 2.9 \pm 0.1,21,2 \\
(7.6-8.8) \quad(2.8-3.0)\end{array}$ & $\begin{array}{l}7.0 \pm 0.2 \times 2.0 \pm 0.1,27,2 \\
(6.4-7.6) \quad(1.8-2.2)\end{array}$ \\
\hline & $\begin{array}{l}6.6 \pm 0.6 \times 2.3 \pm 0.2,25,2 \\
(5.8-7.6) \quad(2.0-2.6)\end{array}$ & \\
\hline Marginal cirri & $\begin{array}{l}4.8 \pm 0.7 \times 1.8 \pm 0.2,22,2 \\
(4.0-6.4) \quad(1.6-2.0)\end{array}$ & $\begin{array}{l}13.3 \pm 0.6 \times 4.5 \pm 0.2,26,3 \\
(12.4-14.6)(4.44 .8)\end{array}$ \\
\hline Manubrium & Absent & $\begin{array}{l}7.0 \pm 0.2 \times 2.0 \pm 0.1,15,1 \\
(6.4-7.2) \quad(1.8-2.0)\end{array}$ \\
\hline
\end{tabular}

\section{Gametes and sparening time}

The size of sperm was measured in one male medusa from Akajima Island on a few days after collection. The length of head and middle piece together was $2.6-2.8 \mu \mathrm{m}(\mathrm{N}=4)$ and the greatest width was $1.8-2.0 \mu \mathrm{m}(\mathrm{N}=4)$. The tail was 46-56 $\mu \mathrm{m}$ in length $(\mathrm{N}=5)$.

The diameter of unfertilized eggs was measured on five occasions immediately 


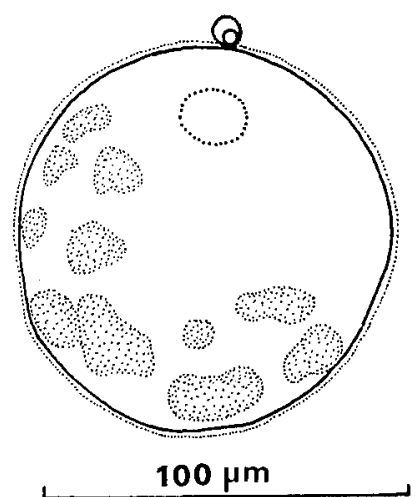

Fig. 8. Unfertilized egg of Cirholovenia tetranema, immediately after spawning. Note many opaque inclusions.

after discharge from the gonads of a female medusa from Akajima Island. The diameter varied from 97.6 to $112.0 \mu \mathrm{m}$ with the mean and standard deviation of $103.5 \pm 3.9 \mu \mathrm{m} \quad(\mathrm{N}=25)$. Spawning occurred approximately 60 minutes after dark. The eggs spawned were not entirely transparent, but contained many opaque inclusions (Fig. 8).

\section{Remarks}

The synonymy of Eugymnanthea minuta Uchida from the Gulf of Naples with the present species was already mentioned by Kubota (1978, p. 141). Uchida's (1964) two specimens are the first record of Cirrholovenia tetranema in the Mediterranean and the second record of this species in the world.

The number of statolith per statocyst of the present specimens caught in the sea is usually less than that of the above-mentioned specimens from the Mediterranean described by Uchida (1964), while the same as that in the specimens collected from Brazil by Moreira (per. comm.)(see Table 4). However, in some statocysts of the laboratory-reared specimens the number increased up to four, overlapping with the number described in the aforementioned specimens from the Mediterranean.

As the number of statocysts is reported to be variable (up to eight) in the original description (Kramp, 1959), the number was demonstrated as a variable character in the present specimens (Table 2). However, most of the specimens grown in the sea (28 out of 31 ) had four statocysts irrespective of the size of medusa and sex. A specimen from Tomari that had three statocysts on capture (Table 1) produced a new statocyst on the 7 th day, and thus had the normal number of statocysts.

The gonads in the present specimens extend from the base of the stomach as in the holotype from the Solomon Islands (Kramp, 1959) and those from Southeast Asia (Kramp, 1959), Mediterranean (Uchida, 1964; Brinckmann, 1965; Goy, 1972; Goy, Lakkis \& Zeidane, 1991), North American Atlantic (Allwein, 1967), and the South American Atlantic (Moreira, 1967, 1975). However, some specimens collected from the Mediterranean (Uchida, 1964), the Brazilian coast (Goy, 1979), the Chinese 
Table 4. Morphological comparison of the medusa of Cirrholovenia tetranema around the world.

\begin{tabular}{|c|c|c|c|c|c|c|c|}
\hline $\begin{array}{l}\text { Locality } \\
\text { (sce } \\
\text { Fig. 9) }\end{array}$ & $\begin{array}{l}\text { Umbrellar } \\
\text { diameter } \\
(\mathrm{mm})\end{array}$ & $\begin{array}{l}\text { No. of } \\
\text { stato- } \\
\text { cysts }\end{array}$ & $\begin{array}{l}\text { No. of } \\
\text { stato- } \\
\text { liths/ } \\
\text { statocyst }\end{array}$ & $\begin{array}{l}\text { No. of } \\
\text { marginal } \\
\text { cirri } \\
\text { quadrant }\end{array}$ & $\begin{array}{l}\text { Connection } \\
\text { of gonads } \\
\text { with the } \\
\text { stomach }\end{array}$ & $\begin{array}{l}\text { No. of } \\
\text { medusae } \\
\text { examined }\end{array}$ & References \\
\hline $\begin{array}{l}\text { Solomon } \\
\text { Islands* } \\
\text { \& SE Asia }\end{array}$ & below 1.5 & $4^{*}$ or 8 & - & up to $8^{*}$ & connected ${ }^{*}$ & $7^{2)}$ & Kramp, 1959 \\
\hline $\begin{array}{l}\text { Papua } \\
\text { New Guinea }\end{array}$ & below 1.4 & $\begin{array}{c}4, \\
\text { rarely } 7\end{array}$ & $\mathrm{x}$ & up to 9 & $\begin{array}{l}\text { connected or } \\
\text { separated }\end{array}$ & $50^{2,3)}$ & $\begin{array}{l}\text { Bouillon, } \\
\text { 1984b }\end{array}$ \\
\hline Italy & $0.88-0.99$ & 4 or 6 & $3-4$ & $4-9$ & $\begin{array}{l}\text { connected or } \\
\text { separated }\end{array}$ & $2^{3)}$ & Uchida, 1964 \\
\hline Italy & $1.7 * *$ & 4 & - & $4-5^{* *}$ & connected $^{* *}$ & $1^{3)}$ & $\begin{array}{l}\text { Brinckmann, } \\
1965\end{array}$ \\
\hline France & below 1.0 & $\begin{array}{c}4, \\
\text { rarely } 8\end{array}$ & - & up to $6^{1)}$ & connected & 15 & Goy, 1972 \\
\hline Lebanon & $2 * *$ & $\begin{array}{c}4 \\
\text { or more }\end{array}$ & - & 7 & connected & 20 & $\begin{array}{c}\text { Goy, Lakkis \& } \\
\text { Zeidane, } 1991\end{array}$ \\
\hline USA & 2.8 & 4 & - & $6-8$ & connected & 1 & Allwcin, 1967 \\
\hline Brazil & below 1.7 & 4 & 1 & up to 8 & connected & 40 & $\begin{array}{c}\text { Moreira, 1975, } \\
\text { per. comm. }\end{array}$ \\
\hline Brazil & below 1.5 & 4 & - & $8^{* *}$ & separated & $2^{2)}$ & Goy, 1979 \\
\hline China & $\begin{array}{l}\text { at least } \\
3.2 * *\end{array}$ & 4 & - & $7-8$ & separated & 7 & $\begin{array}{l}\text { Xu \& Zhang, } \\
1981\end{array}$ \\
\hline Japan & below 2.50 & $\begin{array}{l}\text { usually } 4, \\
\text { up to } 9\end{array}$ & $\begin{array}{l}\text { usually } \\
1, \text { up to } 4\end{array}$ & up to 15 & connected & $33^{2,3)}$ & $\begin{array}{l}\text { Kubota, } \\
\text { present study }\end{array}$ \\
\hline
\end{tabular}

*: Type locality and the character state of the holotype.

**: Read from the figure of the paper.

$\therefore$ No description. $\mathrm{x}$ : unavailable.

1): $24 / 4$.

2): At least one specimen is femalc.

3): At least one specimen is malc.

coast (Xu \& Zhang, 1981), and from the Papua New Guinea (cf. Bouillon, 1984b) have gonads separated from the stomach. Such a difference in the position of the gonads, irrespective of the size of medusa (see Table 4), can be linked with the physiological status of medusae. As a matter of fact, it was observed in the present 
medusae reared in the laboratory that the proximal portion of radial canal became swollen on swallowing the food, and as a result of such swellings the gonads appeared as if they were those directly connected with the stomach.

The marginal cirri are very variable in number irrespective of the size of the mature medusa, and up to 15 cirri have been found in a quadrant (Tables 2, 4). According to physiological conditions the number easily changes as was demonstrated in the present rearing.

As in the case of Mediterranean specimens (Brinckmann, 1965), the present medusa is supposed to have shed eggs in the early morning since it spawned eggs around one hour after dark. But, Brinckmann (1965) observed the other spawning of eggs during the night.

The primary hydroid and a very tiny, stolonial colony were obtained from the medusae with the gonads extending from the stomach base by the laboratory-rearing by Brinckmann (1965, pp. 13-14, Figs. 2, 3) and also by Moreira (1975, p. 557). Their hydroids of $C$. tetranema surely belong to the Thecata and are placed in the hydroid genus Cuspidella Hincks, 1868 by Brinckmann (1965). Therefore, Uchida's (1964) conjecture that the hydroid of $C$. tetranema (originally described as Eugymnanthea minuta) is misleading. It was observed that from the hydroids commensal with Mytilus edulis galloprovincialis in Italy medusae of Eugymnanthea inquilina Palombi are exclusively liberated (Kubota, 1989; Piraino et. al., 1994).

\section{Geographical distribution}

The present new record in Asou Bay, Tsushima Island is the northernmost

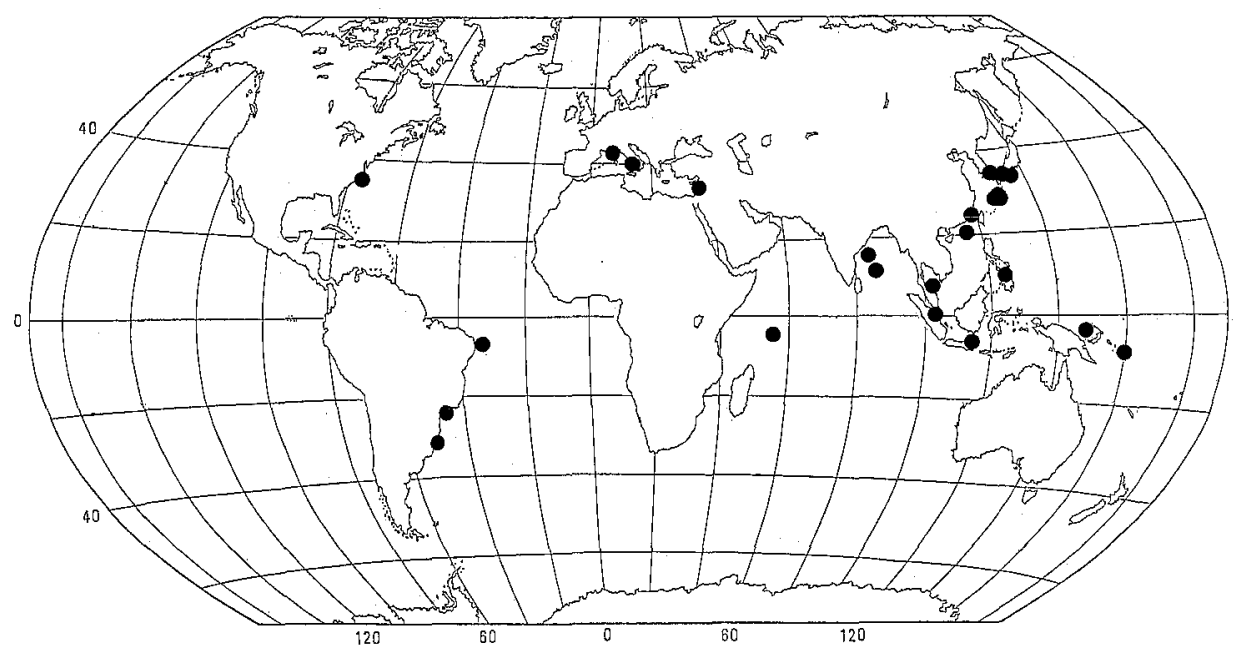

Fig. 9. Geographical distribution of the medusa of Cirrholovenia tetranema, compiled from Kramp (1959), Uchida (1964), Brinckmann (1965), Allwein (1967), Navas (1971), Moreira (1975), Bouillon (1978, 1984b), Goy (1972, 1979), Navas-Pereira (1981), Xu and Zhang (1981), Brinckmann-Voss (1987), Goy, Lakkis \& Zeidane (1991), Mao \& Jinbiao (1991), and the present study. 
geographical distribution of this species in the Pacific (Fig. 9). All other specimens in Japan are also new localities (see Fig. 1). Furthermore, the present species is a new member in the Japanese fauna.

The previous records of the medusae of Cirrholovenia tetranema are the following (Fig. 9): near Solomon Islands (Kramp, 1959), the South China Sea (Kramp, 1959; Xu \& Zhang, 1981); the Taiwan Strait (Mao \& Jinbiao, 1991); the Gulf of Siam (Kramp, 1959); the Java Sea (Kramp, 1959), the Strait of Malacca (Kramp, 1959); the Bismark Sea, Papua New Guinea (Bouillon, 1984b); the Indian Ocean (Navas, 1971; Bouillon, 1978); the North American Atlantic (Allwein, 1967); the South American Atlantic (Moreira, 1967, 1975; Goy, 1979; Navas, 1981); the Mediterranean (Uchida, 1964; Brinckmann, 1965; Goy, 1972; Brinckmann-Voss, 1987; Lakkis, 1991; Goy, Lakkis \& Zeidane, 1991). Therefore, C. tetranema appears to have a wide distribution extending from the tropics to the temperate regions. It is noteworthy that the medusae have not been recorded from the east coasts of the Pacific and the Atlantic Ocean.

\section{Acknowledgements}

I would like to express my sincere thanks to Drs. Jean Bouillon, Jaqueline Goy, and Glória Soares Moreira for their valuable informations. Prof. Jean Bouillon kindly lend me many specimens collected from Papua New Guinea for morphological comparison and read the manuscript. Dr. T. V. Raveendran also kindly read the manuscript, to whom I wish to express my sincere gratitude. Cordial thanks are due to Messrs. Tsuyoshi Hayashibara, Kikuo Okita, Kazuyuki Shimoike, Yoshikazu Yamamoto for their kind help in collecting material. This study was supported by a grant-in-aid for scientific research from the Showa Scitoku Kinen Zaidan and from the Ministry of Education, Science and Culture, Japan (No. 04640683).

\section{References}

Allwein, J. 1967. North American hydromedusae from Beaufort, North Carolina. Vidensk. Medd. Dansk. naturh. Foren., 130: 117-136.

Bouillon, J. 1978. Hydroméduses de l'archipel des Séchelles et du Mozambique. Rev. Zool. afr., 92: 118-172.

- 1984a. Révision de la famille des Phialuciidae (Kramp, 1955) (Leptomedusae, Hydrozoa, Cnidaria), avec un essai de classification des Thecatae-Leptomedusae. Indo-Malayan Zool., 1: 1-24.

- 1984b. Hydroméduses de la Mer de Bismarck (Papouasie, Nouvelle-Guinée). Partie IV: Leptomedusac (Hydrozoa-Cnidaria). Indo-Malayan Zool., 1: 25-112.

-1985. Essai de classification des Hydropolypes-Hydroméduses (Hydrozoa-Cnidaria). IndoMalayan Zool., 1: 29-243.

Brinckmann, A. 1965. The life cycle of the medusa Cirrholovenia tetranema Kramp, 1959 (Leptomedusae, Lovenellidae) with a hydroid of the genus Cuspidella Hincks. Can. J. Zool., 43: 13-15.

Brinckmann-Voss, A. 1987. Seasonal distribution of hydromedusae (Cnidaria, Hydrozoa) from the Gulf of Naples and vicinity, with observations on sexual and asexual reproduction in some species. In: Bouillon, J, Boero, F., Cicogna, F. \& Cornelius, P. F. S. (eds.) 1987. Modern Trends in the Systematics, Ecology, and Evolution of Hydroids and Hydromedusae. Oxford Univ. Press, London: $133-141$.

Goy, J. 1972. Les hydroméduses de la mer Ligure. Bull. Mus. natn. Hist. nat., Paris, (3), 83, sept.-oct. 1972, Zool., 62: 965-1008.

- 1979. Campagne de la Calypso au large des côtes atlantiques de l'Amérique du Sud (1961-1962)-35 Méduses. Rés. scient. Camp. Calypso 11: 263-296.

_ Lakkis, S. \& Zeidane, R. 1990. Les Méduses de la Méditerranée orientale. Bull. Inst. Océanogr., 
Monaco, no sp. 7: 79-88.

$\longrightarrow$ - - \& 1991. Les Méduses (Cnidaria) des eaux Libanaises. Ann. Inst. Océanogr., Paris, 67(2): 99-128.

Kramp, P. L. 1959. Some new and little-known Indo-Pacific medusae. Vidensk. Medd. Dansk. naturh. Foren. Kbh., 121: 223-259.

- 1961. Synopsis of the medusae of the world. J. mar, biol. Ass. UK, 40: 7-469.

- 1968. The hydromedusae of the Pacific and Indian Oceans (II \& III). Dana Rep., 72: 1-200.

Kubota, S. 1978. The polyp and medusa of a commensal eutimid hydroid associated with a mussel from Oshoro, Hokkaido. Annot. zool. Japon., 51(3): 125-145.

- 1989. Systematic study of a paedomorphic derivative hydrozoan Eugymnanthea (ThecataLeptomedusae). Zool. Sci., 6(1): 147-154.

Lakkis, S. 1991. Aggregations of the scyphomedusa Rhizostoma pulmo in the Lebanese coastal waters during the summer of 1986 . Jellyfish blooms in the Mediterranean. In: Proceedings of the II Workshop on Jellyfish in the Mediterranean Sea (Trieste, 2-5 Sept. 1987). MAP Technical Reports Series, 47: 119-127.

Mao, L. \& Jinbiao 1991. Ecological studies of the hydromedusae and ctenophores in the western Taiwan Strait. Acta Oceanol. Sinica, 10(2): 303-310.

Moreira, G. S. 1967. Nova ocorrência e algumas contribuições á biologia de Cirrholovenia ietranema Kramp, 1959. Ciência e Cultura, S. Paulo, 19(2): 426-427.

- 1975. Sobre duas Leptomedusae do litoral do estado de São Paulo. Giência e Cultura, 27(5): $556-558$.

- 1978. A preliminary laboratory study on the salinity and temperature tolerances of some medusae from the São Paulo coast, Brazil. Bolm. Inst. oceanogr., S. Paulo, 27(2): 45-55.

Navas, D. 1971. New records of hydromedusac from the Indian Ocean. Controçoes Inst. oceanogr. Univ. S. Paulo, sér. Ocean. Biol., 22: 1-33.

Navas-Pereira, D. 1981. Distribuiçao das Hidromedusas (Cnidaria, Hydrozoa) na regiao da plataforma continental do Rio Grande do Sul. In: Academia Brasileira de Ciências (ed.), Seminârios de Biologia Marinha, pp. 221-276.

Piraino, S., Todaro, C., Geraci, S. \& Bocro, F. 1994. Ecology of the bivalve-inhabiting hydroid Eugymnanthea inquilina in the coastal sounds of Taranto (Ionian Sea, SE Italy). Mar. Biol., 118: 695-703.

Rees, W. J. 1967. A brief survey of the symbiotic associations of Cnidaria with Mollusca. Proc. malac. Soc. Lond., 37: 213-231.

Uchida, T. 1964. Medusae of Eugymnanthea, an epizoic hydroid. Publ. Scto Mar. Biol. Lab., 12(1): 101-107.

$\mathrm{Xu}, \mathrm{Z}$. \& Zhang, J. 1981. On the hydromedusae from the continental shelf waters of northern part in the South China Sea. Acta Scient. Natur. Univ. Amoiensis, 20(3): 373-382. 